\title{
O Acordo de não Persecução Penal e sua Aplicabilidade no Âmbito do Poder Judiciário a Partir da Vigência da Lei 13.964/19
}

\author{
The Criminal non-Persecution Agreement and it's Applicability within the Ambit of Judicial \\ Power from the Validity of Law 13.964/2019
}

\author{
Giovana Beatriz Schossler ${ }^{1}$ \\ Jonatan Tobias Presser ${ }^{1}$ \\ ${ }^{1}$ Universidade do Vale do Taquari - Univates, Brasil
}

\begin{abstract}
Resumo
Com o advento da Lei 13.964/19, que incluiu o artigo 28-A no Código de Processo Penal, criou-se o instituto da justiça penal consensual, denominado de acordo de não persecução penal. Essa pesquisa traz como objetivo tratar das discussões que surgiram no tocante à legalidade do acordo de não persecução penal e das possíveis divergências que possam existir sobre a sua aplicação no âmbito do Poder Judiciário. Concluiu-se que o instituto é promissor no sentido de evitar o processo penal, poupando tempo e recursos ao Estado, além de ser benéfico para o investigado. Tornou-se conclusiva a existência de divergência na aplicação dos acordos nos tribunais, mormente no tocante à intertemporalidade para sua celebração.

Palavras-chave: Direito penal e processo penal; Justiça penal consensuada; Acordo de não persecução penal; Lei 13.964/19

Abstract

With the advent of Law 13.964 / 2019, which included article 28-A in the Code of Criminal Procedure, the consensual criminal justice institute was created, named the non-criminal prosecution agreement. This research aims to address the discussions that have emerged regarding the legality of the non-criminal prosecution agreement and the possible differences that may exist regarding its application within the ambit of the Judiciary. The conclusion is that the institute is promising in avoiding criminal proceedings, saving the State time and resources, besides being beneficial for the investigated. It became conclusive the existence of divergence in the application of the agreements in courts, specifically regarding inter temporality for its closure.
\end{abstract}

Keywords: Criminal law and criminal procedure; Consensual criminal justice; Non-criminal prosecution agreement; Law 13.964/19

\section{Introdução}

O Direito Penal e Processual Penal Brasileiro traz inovações ao ordenamento jurídico pátrio, principalmente no que tange à celeridade da persecução penal a crimes considerados mais graves.

Assim, a Lei 13.964/19 trouxe inúmeras inovações às matérias penais da legislação brasileira e, dentre elas, o instrumento que possibilita acordo de não persecução penal firmado entre o Ministério Público e o investigado, devidamente homologados por magistrado, aos crimes de pena mínima inferior a quatro anos e que não tenham sido cometidos com violência ou grave ameaça.

Nessa banda, o problema do presente artigo é analisar se os acordos de não persecução penal estão sendo implementados de forma uniforme no âmbito do Poder Judiciário, a partir da vigência da Lei 13.964/20. 


\section{Justiça Penal Consensual}

Para melhor compreensão do inovador instituto processual penal - acordo de não persecução penal - imprescindível contextualizarmos a evolução histórica da justiça penal consensual, correlacionando-a com o referido acordo, objeto direto do presente artigo.

\subsection{Contextualização histórica}

Diante de um imenso número de processos penais que se amontoam no Poder Judiciário, necessário reanalisar os procedimentos existentes no ordenamentojurídico no que tange a sua resolução.

Assim, com o advento da Constituição Federal de 1988, começou-se a pensar em justiça penal consensual, posto que o artigo 98 (caput e inciso I) previu a criação de juizados especiais, com juízes togados ou leigos, competentes para dirimir conflitos de menor complexidade da sociedade, bem como para julgar e executar infrações penais de menor potencial ofensivo.

Assim, “[...] a Lei 9.099/95 representou um marco no processo penal brasileiro, na medida em que, rompendo com a estrutura tradicional de solução dos conflitos, estabeleceu substancial mudança na ideologia até então vigente" (LOPES JUNIOR, 2020, p. 821).

Argumenta o mesmo doutrinador que, além da criação dos juizados especiais criminais, que marcaram, sobretudo, o ingresso do "espaço negocial", surgiram outros importantes procedimentos no processo penal, os quais serão demonstrados mais adiante (LOPES JUNIOR, 2020).

Necessário salientar ainda que o legislador constituinte, ao prever o artigo 98 da Constituição Federal, além de visar a celeridade da prestação jurisdicional e dar maior seguridade à vítima, objetivou estabelecer algumas medidas despenalizadoras (AVENA, 2019).

Assim, pode-se concluir que somente no ano de 1988, começaram a ser previstos no ordenamento jurídico, soluções consensuais de justiça penal e que, em momento posterior, foram sendo cada vez mais enraizadas e utilizadas para um bom andamento jurisdicional. Desse modo, descrever-se-á abaixo os modelos consensuais penais já existentes no Brasil.

\subsection{Modelos consensuais}

Como já visto, o consenso na justiça criminal teve sua primeira aparição legal na Constituição de 1988. Além dessa previsão, fez-se necessária a criação de mecanismos para viabilizar essa inovação legislativa, os quais serão demonstrados a seguir.

\subsubsection{Colaboração premiada}

Embora tenha sido a Lei 9.099/95 a que mais trouxe inovações para a justiça penal consensual, já havia indícios de uma justiça consensual colaborativa quando da criação da Lei 8.072/90. Denominada Lei dos Crimes Hediondos, no parágrafo único do artigo $8^{\circ}$, previa diminuição de pena ao agente infrator participante ou associado, que denunciasse à autoridade pública pessoas que estivessem envolvidas com a formação de bando ou quadrilha. Percebe-se que, naquela época, a justiça consensual já vinha buscando o espaço que até então era ainda muito litigioso.

No ano de 2013 entrou em vigência a Lei 12.850/13 que normatizou, quase que exclusivamente, o instituto da colaboração premiada, prevendo os procedimentos e a aplicação da colaboração premiada no ordenamento jurídico.

Vasconcellos (2017) afirma existir instituto coirmão da colaboração premiada, denominado de acordo de leniência. Previsto na Lei 12.529/11, assemelha-se à colaboração premiada quase que 
integralmente, visto que os dois procedimentos são acordos de trocas de benefícios, sendo o órgão legitimado para sua propositura a distinção mais perceptível entre eles.

Posteriormente, na Lei 9.099/95, que trata dos juizados especiais, surgiram os seguintes institutos: a composição dos danos civis, a transação penal e a suspensão condicional do processo, que serão pormenorizados a seguir.

\subsubsection{Composição dos danos civis}

A composição dos danos civis, com previsão nos artigos 74 e 75 da referida lei, dispõe sobre espécie alternativa a litígios em que o principal objetivo é a reparação dos danos, gerando à vítima título executivo judicial (LOPES JUNIOR, 2020).

Nesse sentido, o título executivo gerado com a homologação do acordo será executável no juízo cível competente, não produzindo efeitos na esfera penal, porquanto acarretará a renúncia do direito de representação, nas ações que a exigem, bem como renúncia à queixa-crime nas infrações penais de ação penal privada (ARAÚJO; COSTA, 2020).

Ressalta-se que há entendimentos doutrinários divergentes acerca da composição de danos civis nas infrações penais de ação pública incondicionada. Alguns doutrinadores entendem ser inviável (LOPES JUNIOR, 2020) ao passo que outros a consideram viável (AVENA, 2019). Este último salienta que existe uma exceção quanto à impossibilidade da composição de danos civis nos delitos de ação incondicionada - os crimes ambientais de menor potencial ofensivo.

Por conseguinte, é importante salientar que para seus efeitos é imprescindível que a infração penal praticada tenha pena máxima igual ou inferior a 2 anos, bem como seja ação que fique condicionada à representação do ofendido ou condicionada à queixa-crime da vítima.

\subsubsection{Transação penal}

Além da composição dos danos civis, a Lei 9.099/95 trouxe (no artigo 76) a inovação denominada de transação penal, modalidade avocada pelo Ministério Público nos crimes de ação penal incondicionada e condicionada. Nesta, se o ofendido representou, poderá ser oportunizada ao infrator a aplicação imediata de pena restritiva de direitos ou multas, dependendo da proposta oferecida pelo Ministério Público.

Ademais, quando o infrator preencher os requisitos de formalidade exigidos no artigo 76 e incisos da lei dos juizados especiais, caberá ao Ministério Público oferecer a transação penal, independentemente de o ofendido achar conveniente ou não, frisando-se, todavia, que, nas infrações penais cuja ação for privada - que dependa de queixa-crime -tocará ao ofendido a oferta da realização da transação penal (AVENA, 2019).

Além disso, se preenchidos os requisitos para a realização da transação penal, poderá o próprio querelante propor, e não o fazendo, poderá ser proposta pelo Ministério Público (LOPES JUNIOR, 2020).

Sublinha-se, entretanto que, sendo caso de ação penal condicionada à representação ou ação penal privada, não se chegará à proposta de transação penal quando houver anteriormente sido homologada a composição dos danos civis, visto que esta ocasionará a renúncia do direito de queixa e representação, extinguindo a punibilidade do infrator (ARAÚJO; COSTA, 2020).

O que se pretende com a descrição minuciosa da transação penal é demonstrar a similitude desta com o acordo de não persecução penal, pelo fato dos dois modelos serem consensuais e acontecerem antes da propositura da ação penal, diferenciam-se, praticamente, somente no que tange à quantidade de pena, pois no primeiro a pena do crime não pode ultrapassar 2 anos, enquanto que neste a pena mínima deve ser inferior a 4 anos. 


\subsubsection{Suspensão condicional do processo}

Além da composição dos danos civis e da transação penal, existe o procedimento denominado de suspensão condicional do processo, previsto também na Lei 9.099/95, especificamente em seu artigo 89.

Da leitura desse artigo, percebe-se que a suspensão condicional do processoé uma proposta oferecida pelo Ministério Público (normalmente acompanhada da denúncia contra o autor do fato) nas infrações penais em que a pena mínima cominada seja igual ou inferior a um ano, independente da pena máxima prevista para o delito.

Nessa proposta, se o acusado preencher os requisitos exigidos pela legislação e aceitar cumprir com as obrigações propostas pelo Ministério Público, após a homologação judicial, seu processo ficará suspenso por um prazo determinado de 2 a 4 anos, não precisando submeter-se a persecução penal, além de não haver assunção da culpa.

Embora pela leitura do artigo 89 da Lei 9.099/95, o oferecimento da suspensão condicional do processo pareça ser exclusividade do Ministério Público, modernos entendimentos doutrinários admitem, também, nos crimes de ação penal privada, em razão do querelante ser o titular da ação penal, cabendo a ele o oferecimento (ou não) da suspensão (LOPES JUNIOR, 2020).

Por fim, verifica-se que os modelos de justiça consensual penal existentes se assemelham com o acordo de não persecução penal em vigor a partir do ano de 2020, especialmente por terem em sua essência as mesmas justificativas, bem como procedimentos semelhantes, sendo viável, portanto, sua aplicação, sem ofender e contrariar qualquer legislação.

Nesse diapasão, serão estudados os principais benefícios que a resolução consensual de crimes ostenta no nosso ordenamento jurídico.

\subsection{Benefícios da resolução consensual para o processo penal}

Os meios alternativos de resolução de conflitos estão adquirindo mais espaço, principalmente pelo fato de o Poder Judiciário não conseguir dar o devido andamento aos processos, colocando em risco a segurança jurídica, bem como colocando sob pressão e análise a eficácia da duração razoável do processo.

Da mesma forma, os procedimentos consensuais trouxeram benefícios às pessoas e órgãos que entrelaçam as relações jurídicas penais; o acordo de não persecução penal também atingirá sua finalidade, sobretudo, para a sociedade que clama por justiça sem entender as dificuldades que os órgãos enfrentam para lidar com tanta demanda.

Portanto, pode-se citar que existem basicamente três soluções que poderiam auxiliar o Poder Judiciário com os excessos de processos: aumentar o quadro de servidores que atuam no sistema de justiça criminal; uma considerada monta de descriminalização de condutas consideradas infrações penais; e ampliação de modelos consensuais de resolução de conflitos, sobretudo nos delitos de média e baixa complexidade (CABRAL, 2020).

Ademais, é inviável descriminalizar maciçamente certos delitos, uma vez que corriqueiramente aportam o Poder Judiciário infrações penais como, por exemplo, furto, roubo, estelionato, dentre outros - que são condutas intoleráveis pela sociedade e são as de maior incidência (CABRAL, 2020).

A solução consensual parece ser mais conveniente também sob a ótica do Estado, uma vez que investimentos com servidores (necessários no sistema de justiça criminal) afetaria diretamente seu orçamento e economia, concluindo-se que formas consensuais são menos onerosas e menos morosas.

Por outro viés, as soluções negociadas de resolução de conflitos trazem aos acusados ou investigados benefícios que no processo penal, em sua plenitude, não se alcançariam. 
Na composição dos danos civis, o principal benefício ao infrator, após a homologação do acordo é a renúncia do direito de queixa ou representação da vítima, evitando possível instauração do processocrime (LOPES JUNIOR, 2020).

Isto é, resolve-se o conflito antes do processo, evitando-se o desgaste da persecução penal aos litigantes e, ainda, praticamente, se evita o uso da máquina estatal, sem contar que a vítima tem sua pretensão atendida de maneira mais célere.

Na transação penal, os efeitos positivos para o Estado são os mesmos da composição dos danos civis - evitar o processo, não se utilizando da máquina e de seus operadores por tempo demasiado. Já ao investigado, estando adimplidas suas obrigações com o Ministério Público, viabiliza-se a não inscrição de seu nome nos assentamentos de antecedentes criminais, além de evitar a persecução penal. A pena de multa ou restritiva de direitos - será antecipada, evitando-se também o desgaste temporal que existe no processo para no final chegar-se a um mesmo resultado.

Com essa antecipação de pena ao infrator, a vítima e a sociedade são presenteadas com a celeridade e pronta aplicabilidade da lei (posto que o agente delituoso desde logo passa a cumprir a sanção), evitando desgaste para ambos.

Por fim, e, não menos importante, salienta-se que todas as formas consensuais de resolução de conflitos penais deverão acontecer na presença de defesa técnica, respeitando-se o direito constitucional da ampla defesa.

Portanto, se o investigado ou acusado, bem como seu defensor não acharem conveniente o acordo, não serão obrigados a assinar, respeitando-se suas decisões. Entretanto, a denúncia (ou o processo) prosseguirá seu curso normalmente, sem prejuízo algum ao infrator, dando-se toda a garantia constitucional do devido processo legal.

\subsection{A mitigação ao princípio da obrigatoriedade da ação penal}

A resolução consensual de conflitos na esfera penal gera discussões, sobretudo, da obrigatoriedade que o Ministério Público detém de ingressar com a ação penal, em razão do princípio da obrigatoriedade da ação penal. Outrossim, quando houver indícios de autoria e materialidade referente à prática de alguma infração penal e, não havendo causas que extinguem a punibilidade, deveria o Ministério Público, em tese, ingressar com a ação penal (AVENA, 2019).

Desta forma, se presentes as condições que justificam a ação penal pública - fato aparentemente criminoso, punibilidade concreta e justa causa - o Ministério Público tem o dever de oferecer a ação penal, uma vez que esta é subsidiada pelo princípio da obrigatoriedade (LOPES JUNIOR, 2020).

Pauta-se que a obrigatoriedade não é absoluta, sendo ela relativizada em razão da possibilidade de transação penal, possibilitando ao Ministério Público deixar de oferecer a ação penal, oferecendo ao autor do fato - desde que preenchidos os requisitos - a aplicação imediata de sanções penais que não preveem a privação de liberdade, findando assim o procedimento (AVENA, 2019).

Como visto, a mitigação em análise confere, de certa forma, legalidade à justiça penal consensual, tendo em vista que o Ministério Público, ao deixar de oferecer a denúncia e pactuar com o autor do fato, não estaria exercendo a sua função de ofício, afrontando assim o princípio da obrigatoriedade da ação penal.

A justiça penal consensual já estava presente no bojo dos processos criminais. Assim que o novo modelo passou a vigorar, no ano 2020, denominado de acordo de não persecução penal, apenas concedeu elasticidade àquilo que já vinha sendo aplicado de forma reiterada pelo Poder Judiciário, como a seguir explorado. 


\section{Análise do Acordo de não Persecução Penal}

Após o estudo dos institutos de justiça penal negociada que, de certo modo, foram modelos para subsidiar a implementação desse nosso novo e promissor instituto, passar-se-á a analisar o objeto direto do presente artigo - o acordo de não persecução penal previsto no artigo 28-A do Código de Processo Penal.

\subsection{Requisitos do acordo de não persecução penal}

O acordo de não persecução penal foi, inicialmente, previsto na Resolução 181/17 editada pelo Conselho Nacional do Ministério Público. Posteriormente, no ano de 2018, realizou alguns ajustes no instituto, com a edição da Resolução 183/18. Atualmente, o acordo supracitado tem sua regulamentação no artigo 28-A do Código de Processo Penal, o qual definiu alguns requisitos, conforme a seguir detalhados.

\subsubsection{Não ser caso de arquivamento}

Para a celebração do acordo de não persecução penal é imprescindível que peças informativas como o inquérito policial, o procedimento de investigação criminal, dentre outros, estejam com suas condições mínimas preenchidas para uma eventual ação penal (CABRAL, 2020).

Não havendo indícios de materialidade delitiva, bem como inexistindo indícios mínimos de autoria ou participação na prática do delito, não resta outra alternativa ao Ministério Público senão o arquivamento do feito, conforme previsão do artigo 28 do Código de Processo Penal ${ }^{1}$ não se justificando, inclusive, a proposta do acordo de não persecução (MOSSIN; MOSSIN 2020).

Importante frisar que o acordo não pode ser instituto de obtenção de justa causa, somente sendo possível sua celebração se esta já existir (CABRAL, 2020).

\subsubsection{Pena mínima inferior a quatro anos}

No que tange à infração penal ter pena mínima inferior a 4 (quatro) anos, deve-se levar em consideração as causas de aumento e diminuição da pena aplicáveis ao caso concreto ${ }^{2}$, utilizando-se de base a pena mínima abstrata e, se houver causa de aumento de pena, a menor fração; mas, havendo causa de diminuição se utilizará a maior fração (CUNHA, 2020).

Ademais, não devem ser consideradas para o cálculo da pena mínima as circunstâncias agravantes e atenuantes, visto ser critério aplicado especificamente pelo magistrado quando da fixação da pena com quantidades variadas previstas nas leis (MOSSIN; MOSSIN, 2020).

\subsubsection{Confissão formal e circunstanciada}

No tocante ao requisito da confissão formal e circunstanciada existe, sem dúvidas, uma grande discussão. Antes mesmo da vigência da Lei 13.964/19, o entendimento era de que a confissão do investigado seria mais benéfica na celebração do acordo do que a confissão no decorrer do processo (LOPES JUNIOR, 2020).

\footnotetext{
$1 \quad$ Código de Processo Penal: "Art. 28. Ordenado o arquivamento do inquérito policial ou de quaisquer elementos informativos da mesma natureza, o órgão do Ministério Público comunicará à vítima, ao investigado e à autoridade policial e encaminhará os autos para a instância de revisão ministerial para fins de homologação, na forma da lei” (1941, texto digital).

2 Código de Processo Penal: "Art. 28-A $§ 1^{\circ}$ Para aferição da pena mínima cominada ao delito a que se refere o caput deste artigo, serão consideradas as causas de aumento e diminuição aplicáveis ao caso concreto” (1941, texto digital).
} 
No entanto, há divergência no que tange à confissão ser usada de forma ilegítima, no caso de não cumprimento por parte do investigado das obrigações a ele impostas na celebração do acordo; pois, se não forem cumpridas, caberá ao Ministério Público comunicar o magistrado para fins da rescisão do acordo e posteriormente denunciar o investigado pela prática do delito3 .

Nesse sentido, para a efetiva utilização do acordo de não persecução penal, nos casos de descumprimento das obrigações que devem ser cumpridas pelo investigado, é imprescindível a utilização do juízo de garantias, assim como suas funções previstas nos artigos 3-B a 3-F do Código de Processo Penal - embora esse dispositivo esteja atualmente suspenso pelo Ministro Luiz Fux, por ação direta de inconstitucionalidade ${ }^{4}$ (BATTINI; BORRIS; SOARES, 2020).

Nessa seara, é necessário salientar que o juízo de garantias evitaria a utilização da confissão na instrução do processo e que consequentemente, não se empregaria a ela no julgamento de mérito (BATTINI; BORRIS; SOARES, 2020).

Superada a confissão no que tange ao eventual descumprimento por parte do investigado, importante ressaltar que este não é obrigado a comparecer no Ministério Público para confessar a prática de delito, resguardo conferido pelo princípio da não autoincriminação, com previsão no artigo 5ํㅜㄴ, LXIII da Constituição Federal (MESSIAS, 2019).

Salienta-se ainda que a confissão por si só não é capaz de amparar a celebração do acordo, devendo o Ministério Público possuir outros elementos que subsidiem o seu convencimento acerca da materialidade e autoria do delito (BARROS; ROMANIUC, 2019).

O mais importante de tudo no que se refere à confissão do delito é que todo esse procedimento acontecerá entre o Ministério Público e o investigado acompanhado de seu defensor, devendo o acordo ser homologado em audiência pelo juízo, cabendo a este verificar a voluntariedade e legalidade do feito, conforme previsão nos parágrafos $3^{\underline{0}}$ e $4^{\underline{0}}$ do artigo 28-A do Código de Processo Penal ${ }^{5}$.

Nessa banda, Mossin e Mossin (2020) dissertam que o investigado será assistido por seu defensor, devendo este orientar seu cliente quanto à conveniência ou não de aceitar o acordo, tendo assim o investigado a garantia de que seus direitos estão sendo preservados.

\subsubsection{Sem violência e grave ameaça}

Um dos requisitos para a celebração do acordo de não persecução é que a infração penal cometida não tenha sido praticada com violência e grave ameaça.

Nesse sentido, a legislação estar proibindo a celebração do acordo nos crimes em que tenha havido violência ou grave ameaça na conduta, mas podendo ser celebrado o acordo nos crimes em que houve a violência no resultado, como por exemplo, homicídio culposo (CUNHA, 2020).

Por outro lado, frisa-se que o legislador "[...] realiza uma clara - e legítima - opção políticocriminal de não beneficiar pessoas que tenham praticado delitos que envolvam violência ou grave ameaça” (CABRAL, 2020, p. 90).

Ainda, o legislador não previu a real distinção de culpa ou dolo para a celebração do acordo, como previu no parágrafo único do artigo 71 do Código Penal, não sendo claro e preciso quanto à não aplicabilidade do acordo de não persecução penal nos delitos culposos (CABRAL, 2020).

3 Código de Processo Penal. "Art. 28-A. \$ 10. Descumpridas quaisquer das condições estipuladas no acordo de não persecução penal, o Ministério Público deverá comunicar ao juízo, para fins de sua rescisão e posterior oferecimento de denúncia” (1941, texto digital).

4 Ação Direta de Inconstitucionalidade noㅜ 6299.

5 Código de Processo Penal: “Art. 28-A. $\$ 3^{\circ}$ O acordo de não persecução penal será formalizado por escrito e será firmado pelo membro do Ministério Público, pelo investigado e por seu defensor. $\$ 4^{\circ}$ Para a homologação do acordo de não persecução penal, será realizada audiência na qual o juiz deverá verificar a sua voluntariedade, por meio da oitiva do investigado na presença do seu defensor, e sua legalidade” (1941, texto digital). 
Desta forma, primeira interpretação acerca da aplicabilidade ou não do acordo de não persecução penal aos delitos com resultados culposos é a adequada, sobretudo por parecer mais conveniente celebrar o acordo, pois não há por que não se conceder o benefício ao investigado quando ele realmente não pretendeu tal resultado violento.

\subsubsection{O acordo como meio necessário e suficiente para a reprovação do delito}

Outro requisito que merece destaque é o acordo ser meio necessário e suficiente para a reprovação do delito. Desse modo, esse requisito é ato discricionário do titular do Ministério Público, competindo a ele avaliar se a celebração do acordo é suficiente para reprovação do delito, tendem vista a independência funcional que a Constituição Federal previu a ele no artigo 127, § $1^{\circ} 19$ (CABRAL, 2020).

Nessa perspectiva, deve-se levar em conta a personalidade do infrator e as circunstâncias do fato, visto o procedimento consensuado visar a eficácia para reprimir e prevenir novos delitos; portanto, se não for alcançada essa finalidade, não haverá motivos para a celebração do acordo (MOSSIN; MOSSIN, 2020).

Conclui-se que esse requisito deve apreciar sempre a adequação e a necessidade, isto é, a proporcionalidade (LOPES JUNIOR, 2020).

\subsubsection{Impedimentos para a celebração do acordo}

Com a leitura do parágrafo $2^{o}$ do artigo 28- $\mathrm{A}^{6}$ do Código de Processo Penal é possível perceber que existem causas que impedem o agente infrator de celebrar o acordo de não persecução.

Dentre as causas impeditivas podemos destacar: a) impossibilidade do acordo quando cabível transação penal; b) quando o infrator for reincidente ou quando ele pratica delitos habituais, reiterada ou profissionalmente, salvo se as infrações penais anteriores tiverem sido classificadas como insignificantes; c) o investigado não pode ter usufruído, nos últimos 5 (cinco) anos, de outro acordo de não persecução penal, transação penal ou suspensão condicional do processo; d) não ter sido o crime cometido no âmbito de violência doméstica ou familiar, bem como não ter sido cometido contra mulher em razão do sexo feminino.

Em relação a cada um desses impedimentos, consigna-se:

a) quando for cabível a transação penal, não será possível a celebração do acordo de não persecução, visto este ter caráter subsidiário àquele, ressaltando-se, assim, a sua impossibilidade aos delitos de menor potencial ofensivo (BARROS; ROMANIUIC, 2019). Sublinha-se, entretanto que, o fato de o investigado estar respondendo a outro processo penal, isso por si só, não impede a celebração do acordo (CABRAL, 2020);

b) a reincidência é verificada em pesquisa de folhas de antecedentes do agente, e se configura quando o indivíduo praticar novo delito antes de transcorrido o lapso temporal de 5 (cinco) anos da extinção ou cumprimento da pena. Como habitualidade delitiva, reiterada e profissional entende-se que será habitual quando a prática de cometimento de delitos faz parte da vida do agente; reiterada, quando o indivíduo pratica a mesma infração penal inúmeras vezes; e profissional, por sua vez, quando o agente pratica o crime de forma organizada e aperfeiçoada, não importando o número de vezes que praticou tal ato, abrindo-se exceção se a prática de tais condutas foram, outrora, consideradas insignificantes (CABRAL, 2020);

6 Código de Processo Penal: “Art. 28-A. - $§ 2^{\circ}$ O disposto no caput deste artigo não se aplica nas seguintes hipóteses:I - se for cabível transação penal de competência dos Juizados Especiais Criminais, nos termos da lei; II - se o investigado for reincidente ou se houver elementos probatórios que indiquem conduta criminal habitual, reiterada ou profissional, exceto se insignificantes as infrações penais pretéritas; III - ter sido o agente beneficiado nos 5 (cinco) anos anteriores ao cometimento da infração, em acordo de não persecução penal, transação penal ou suspensão condicional do processo; e IV - nos crimes praticados no âmbito de violência doméstica ou familiar, ou praticados contra a mulher por razões da condição de sexo feminino, em favor do agressor" (1941, texto digital). 
c) no que tange ao investigado não ter sido beneficiado com outros instrumentos consensuais nos últimos 5 (cinco) anos, é necessário ter-se em vista a proposta desses institutos - evitar reiteração de condutas criminosas, sendo inviável a celebração de acordo ao agente que se beneficiou com a negociação em momento anterior;

d) referente à não aplicabilidade do acordo nos casos de violência doméstica ou familiar, bem como contra mulher em razão do sexo feminino, sublinha-se que são casos expressamente proibidos pela legislação, não importando se o crime cometido tenha pena mínima inferior a 4 (quatro) anos.

\subsection{As condições assumidas pelo investigado para a não persecução penal}

Para que ocorra a celebração do acordo de não persecução penal, além do investigado necessitar preencher os requisitos acima mencionados, deverá assumir e cumprir algumas condições dispostas nos incisos do artigo 28-A do Código de Processo Penal 7 .

O primeiro inciso prevê que o investigado deverá reparar o dano ou restituir a coisa à vítima ${ }^{8}$ percebe-se que este é o principal objetivo da celebração do acordo, sobretudo, para satisfazer qualquer prejuízo causado à vítima e à sociedade.

Existe forte relação dessa condição com a composição dos danos cíveis, vez que existe a finalidade restaurativa com a celebração do acordo, pretendendo-se atender em primeiro lugar os interesses do ofendido (ARAS, 2020).

Existem, porém, casos em que não é possível reparar o dano e nem restituir a coisa à vítima, como por exemplo, quando o bem perecer ou nos casos em que o investigado não tenha condições financeiras de reparar o dano. No entanto, Cunha (2020) afirma que não é causa impeditiva à celebração do acordo, visto o próprio inciso prever essa possibilidade na sua parte final, facultando ao Ministério Público fixar outras condições, desde que proporcionais com a infração penal imputada.

Destaca-se ainda que é uma das condições mais importantes do acordo de não persecução penal, tendo em vista que permite à vítima ter voz e vez no processo penal (CABRAL, 2020).

O segundo inciso trata da renúncia voluntária de bens e direitos que o Ministério Público indicar como instrumentos, produtos ou proveitos do crime ${ }^{9}$. Assim, esse patrimônio deve ser renunciado de forma voluntária, pois essa condição é muito importante, sobretudo, por agilizar a transferência dos bens a quem tenha legítimo direito a eles, além de otimizar tempo (no processo os bens ficariam retidos até a sentença penal). Quando realizado o acordo há a imediata resolução da demanda, perfectibilizando de forma efetiva o inciso I do artigo 28-A do Código de Processo Penal.

Os incisos III e IV do referido artigo preveem a prestação de serviço à comunidade ou a entidades públicas, bem como o pagamento de prestação pecuniária; para Mossin e Mossin (2020), essas duas condições têm procedimentos semelhantes à transação penal.

No tempo de prestação de serviço à comunidade será calculada a pena mínima cominada ao delito diminuída de um a dois terços, nos termos do artigo 46 do Código Penal, dependendo do acordo

$7 \quad$ Código de Processo Penal: "Art. 28-A. I - reparar o dano ou restituir a coisa à vítima, exceto na impossibilidade de fazê-lo; II - renunciar voluntariamente a bens e direitos indicados pelo Ministério Público como instrumentos, produto ou proveito do crime; III - prestar serviço à comunidade ou a entidades públicas por período correspondente à pena mínima cominada ao delito diminuída de um a dois terços, em local a ser indicado pelo juízo da execução, na forma do art. 46 do Decreto-Lei no 2.848, de 7 de dezembro de 1940 (Código Penal); IV - pagar prestação pecuniária, a ser estipulada nos termos do art. 45 do Decreto-Lei no 2.848, de 7 de dezembro de 1940 (Código Penal), a entidade pública ou de interesse social, a ser indicada pelo juízo da execução, que tenha, preferencialmente, como função proteger bens jurídicos iguais ou semelhantes aos aparentemente lesados pelo delito; ou V - cumprir, por prazo determinado, outra condição indicada pelo Ministério Público, desde que proporcional e compatível com a infração penal imputada” (1941, texto digital).

8 Código de processo Penal: "Art. 28-A. I - reparar o dano ou restituir a coisa à vítima, exceto na impossibilidade de fazê-lo" (1941, texto digital).

9 Código de Processo Penal: “Art. 28-A. II - renunciar voluntariamente a bens e direitos indicados pelo Ministério Público como instrumentos, produto ou proveito do crime” (1941, texto digital). 
firmado entre Ministério Público e o investigado. E, com relação ao pagamento de prestação pecuniária, deverá ser observado o disposto no artigo 45 do Código Penal (pontualmente o parágrafo 1º), cabendo ao Ministério Público aplicar essa condição dentro dos limites estabelecidos na legislação, utilizando-se do bom senso e análise das condições financeiras do investigado (MOSSIN; MOSSIN, 2020).

$\mathrm{O}$ inciso $\mathrm{V}$ do artigo 28-A trata de o investigado cumprir outras condições indicadas pelo Ministério Público como modo de evitar o processo; destaca-se que o rol de condições do inciso I ao IV é exemplificativo. Desse modo, o acordo de não persecução penal é meio extrajudicial em que as partes convencionam suas condições com respeito à legislação e aos princípios do devido processo consensual, da autonomia da vontade, da eficiência, da lealdade e da boa-fé objetiva (DOWER; SOUZA, 2020).

Para finalizar as condições para a celebração do acordo, ressalta-se que tais requisitos podem ser alternados ou cumulados, conforme previsão do artigo 28-A do Código de Processo Penal. O não cumprimento das condições por parte do investigado possibilitará ao Ministério Público postular ao juízo a sua rescisão, cuja consequência resultará no subsequente oferecimento da denúncia, conforme previsão do parágrafo 10, do mesmo artigo.

\subsection{Da questão intertemporal para aplicabilidade do instituto}

De acordo com o explanado até o momento, percebe-se claramente que o acordo de não persecução penal é instituto extrajudicial e que tem, em regra, a sua celebração antes do recebimento da denúncia, haja vista o Ministério Público ter a legitimidade para propô-lo.

No entanto, há discussão acerca de sua aplicabilidade em processos já em curso, bem como em processos que estejam na fase recursal, isto é, demandas em que já houve o recebimento da denúncia.

Nesse sentido, previu o enunciado número 20 do Caderno de Interpretações da Lei 13.964/2019 do Conselho Nacional de Procuradores-gerais dos Ministérios Públicos dos Estados e da União que "cabe acordo de não persecução penal para fatos ocorridos antes da vigência da Lei nº 13.964/2019, desde que não recebida a denúncia” (GNCCRIM, 2019, p. 6).

No entanto, faz-se necessária a análise do dispositivo, em consonância com o entendimento de Lopes Júnior que inclusive salienta que:

O acordo de não persecução penal poderá ser oferecido aos processos em curso quando da sua entrada em vigor, na medida em que se trata de norma mista (retroage para beneficiar o réu). Também não vislumbramos obstáculos a que seja oferecido em qualquer fase do procedimento, caso não tenha sido acordado no início do feito (LOPES JUNIOR, 2020, p. 224).

Desta forma, respeita-se também o posicionamento de que a norma deve retroagir, haja vista não haver nenhuma restrição objetiva nesse sentido no texto de lei. Acredita-se, também, não ser possível enunciados e provimentos internos determinarem o oferecimento ou não do acordo de não persecução penal (COSTA et al., 2020).

Todavia, em que pese a lei não ter sido tão objetiva quanto à intertemporalidade do instituto, depreende-se que o tempo de sua aplicação é antes do recebimento da denúncia - já que o parágrafo 10 do artigo 28- $\mathrm{A}^{10}$ prevê como solução de um eventual inadimplemento das condições estabelecidas no acordo, a rescisão dele e o oferecimento da denúncia. Ademais, a celebração do acordo é atribuição do Ministério Público; portanto, entende-se que deverá ser antes do processo.

10 Código de Processo Penal: “Art. 28-A. \$10. Descumpridas quaisquer das condições estipuladas no acordo de não persecução penal, o Ministério Público deverá comunicar ao juízo, para fins de sua rescisão e posterior oferecimento de denúncia” (1941, texto digital). 


\subsection{Da atuação da defesa no acordo de persecução penal}

Uma das exigências legais para a celebração do acordo de não persecução penal (e talvez uma das questões mais importantes para a efetiva regularidade do procedimento) é que o acordo não é possível sem que haja a presença de defesa técnica do investigado, conforme previsão do parágrafo $4^{\circ}$ do artigo 28-A do Código de Processo Penal ${ }^{11}$.

Esse quesito é imprescindível para o bom andamento do sistema de justiça, sobretudo por não ter afastado o princípio da ampla defesa, viabilizando ao investigado a paridade de forças para que o acordo, segundo Silva (2020), não tenha um formato de contrato de adesão.

A relevância da presença do defensor é no sentido de orientar o investigado sobre o modelo consensual de justiça penal, avaliando se há provas realmente incriminadoras. Caso existam indícios de autoria capazes de condená-lo, o defensor irá verificar a licitude e, não sendo, vedar o acordo, bem como orientar o investigado sobre os efeitos do não cumprimento das condições, dentre outras funcionalidades (MENDONÇA, 2020).

Portanto, embora o investigado esteja acompanhado de defesa, é necessária a percepção por parte do magistrado sobre a aceitabilidade pelo acordante autor do fato (não sendo apenas vontade do defensor).

Nesse sentido, a defesa tem um papel de atuação mais relevante do que aquele exercido no próprio processo penal, quando se exige uma obrigatoriedade de atuação da defesa por temer-se pela precariedade e ineficiência do princípio da ampla defesa; no acordo de não persecução existe uma quebra desse paradigma, oportunizando-se a ambas as partes, investigado e Estado, escolhas livres e conscientes (DOWER; SOUZA, 2020).

Portanto, durante o processo criminal a autodefesa é dispensável ao procedimento, ao passo que no acordo de não persecução penal somente o autor do fato poderá aceitar o acordo, amparado e orientado por seu defensor (MENDONÇA, 2020).

\subsection{O acordo de não persecução penal e os crimes hediondos ou equiparados}

Os crimes hediondos ou equiparados comumente são cometidos com emprego de violência ou grave ameaça, impossibilitando a celebração do acordo de não persecução penal (BARROS; ROMANIUC, 2019).

No entanto, importante sublinhar que o artigo 28-A do Código de Processo Penal não faz nenhuma objeção à aplicação do instituto ao crime hediondo, porquanto há crimes hediondos ou equiparados que podem ser cometidos sem o emprego de violência e grave ameaça e tenham pena mínima inferior a quatro anos, como é o caso do crime de posse ou porte ilegal de arma de fogo de uso restrito.

Destaca-se que a Resolução número 183 do Conselho Nacional do Ministério Público previa em seu artigo 18 (parágrafo $1^{\circ}$, inciso V) que não se aplicaria o acordo de não persecução penal quando o crime fosse hediondo ou equiparado.

Acredita-se que no atual molde do acordo, previsto no artigo 28-A do Código de Processo Penal, não há nenhuma restrição legal quanto a sua aplicação a crimes hediondos ou equiparados, porquanto poderia o legislador prever a vedação no próprio texto de lei, como ocorreu na resolução supracitada.

Entretanto, pelo fato de os crimes hediondos serem crimes de maior lesividade, acredita-se que o Ministério Público poderá deixar de oferecer o acordo (baseado na premissa de que este não será suficiente para reprovação e prevenção do crime), podendo ainda apresentar outros fundamentos (não

11 Código de Processo Penal: "Art. 28-A. § 4º Para a homologação do acordo de não persecução penal, será realizada audiência na qual o juiz deverá verificar a sua voluntariedade, por meio da oitiva do investigado na presença do seu defensor, e sua legalidade" (1941, texto digital). 
se valendo especificamente do argumento de crime hediondo) para subsidiar sua decisão (BATTINI; BORRIS; SOARES, 2020).

\section{A Prática do Acordo de não Persecução Penal}

Questões pertinentes à prática do acordo de não persecução penal merecem atenção, mormente a apreciação que os tribunais estão conferindo ao inovador modelo de justiça penal consensual.

\subsection{Procedimento e formalidades para a convergência de vontade das partes}

No que tange aos procedimentos e formalidades do acordo de não persecução penal é imprescindível lembrarmos que essa modalidade consensuada é modelo extrajudicial de resolução de crimes.

Assim, tratando-se de acordo, é necessário que haja uma paridade de pretensões e que estas sejam atingidas de forma a efetivar o acordo de modo que Estado e investigado saiam satisfeitos.

Salienta-se que o procedimento cumpre a legalidade possível, bem como, deve-se ter bem definidas as regras do jogo, para que não existam desvantagens de uma das partes sobre a outra.

Desse modo, percebe-se que o artigo 28-A do Código de Processo Penal limitou-se a definir o procedimento como sendo uma ação do Ministério Público de oferecer o acordo ao investigado, depreendendo-se que a celebração do acordo ocorrerá em consequência de um procedimento investigatório criminal, precedido pelo promotor de justiça; contudo, nada obsta que seja ofertado em decorrência de informações advindas de inquérito policial ou outros meios de investigação criminal, pois estes são os métodos mais utilizados no Brasil (CABRAL, 2020).

Assim, após receber os dados informativos de delito por um inquérito, deverá o Ministério Público contatar com o investigado a fim de propor o acordo e, havendo o interesse do investigado, deverá ser instaurado procedimento investigatório criminal, o qual torna-se somente um anexo ao procedimento, auxiliando este, em um esporádico e futuro processo penal (CABRAL, 2020).

No dia da realização do acordo, que poderá se dar na audiência de custódia, as condições devem estar claramente definidas ao investigado - devidamente acompanhado de seu defensor - devendo conter a qualificação completa do investigado, as condições e os prazos a serem cumpridos por ele, valores precisamente definidos de restituição à vítima, dentre outras condições que a legislação permite celebrar (BARROS; ROMANIUC, 2020).

Nessa seara, estando as condições alinhadas, poderá o investigado decidir sobre a celebração ou não do acordo, viabilizando-se o consenso na justiça criminal; salientando-se que a aceitação deve ser voluntária, cabendo ao defensor somente sugerir melhorias e fiscalizar a legalidade dos elementos penais e processuais penais presentes no caso.

\subsection{Do acordo de não persecução: homologação, não homologação e cumprimento}

Após as tratativas do acordo serem pactuadas por escrito entre Ministério Público e investigado é fundamental que ele seja apreciado pelo Poder Judiciário, viabilizando-se segurança ao pactuado.

Desse modo, em audiência o juiz deverá verificar, através da oitiva do investigado, se o acordo de não persecução penal foi celebrado com voluntariedade, bem como analisar a legalidade, devendo o autor do fato estar acompanhado de defesa, conforme previsão do parágrafo $4^{\circ}$ do artigo 28-A do Código de Processo Penal.

Existe discussão acerca da presença do Ministério Público na audiência de homologação, pois a lei não a previu. No entanto, sua presença seria indispensável pelo dever de figurar como titular da 
ação penal, como fiscal da lei e, ainda, para vislumbrar a legalidade dos atos praticados no que tange à persecução ou não da ação penal (CABRAL, 2020).

Na referida audiência, de acordo com o parágrafo 5ํㅜ o magistrado verificará se as condições estabelecidas no acordo não são inadequadas, insuficientes ou abusivas, devolvendo os autos ao Ministério Público para renegociar as cláusulas, com o consentimento do investigado e seu defensor.

Não havendo restrições que impeçam a homologação, ocorrerá a remessa dos autos ao Ministério Público para iniciar a execução perante o juízo de execução penal, conforme disposto no parágrafo $6^{\circ}$ do artigo 28-A.

Os parágrafos $7^{\circ}$ e $8^{\circ}$ do mesmo artigo preveem as hipóteses em que o juízo decidirá por não homologar o acordo. Assim, ocorrendo as hipóteses do parágrafo $7^{\circ}$ - não atendimento dos requisitos legais ou inadequação do previsto no parágrafo $5^{\mathrm{o}}$ - o acordo não produzirá efeitos.

Da mesma forma que ocorre quando da homologação, no caso de recusa será intimado o Ministério Público para complementar as investigações, se necessárias, ou oferecer a denúncia nos termos do parágrafo $8^{\circ}$.

Não sendo efetuadas essas complementações, a homologação poderá ser recusada. Assim, caberá recurso em sentido estrito da decisão que recusar a homologação, por força do artigo 581, inciso XXV, do Código de Processo Penal (MASI, 2020).

Em hipótese de intimação do titular da ação penal para realizar adequações e esse entender não ser caso de adequá-la, poderá encaminhar os autos à instância superior. Ademais, o parágrafo 14 prevê o mesmo procedimento a ser realizado quando o Ministério Público se recusar a oferecer o acordo de não persecução penal (FERREIRA, 2020).

Oferecido o acordo e o investigado concordando com as condições estipuladas, e não havendo negativa de homologação pelo Poder Judiciário, começará a fase de cumprimento das condições ajustadas.

Desta forma, restando cumpridas todas as condições acordadas, o parágrafo 13 dispõe que o investigado terá sua punibilidade extinta pelo juízo competente, beneficiando o investigado, pois não gera registros em certidões de antecedentes criminais (salvo para apreciação de eventual nova homologação de acordo de não persecução, transação penal e suspensão condicional do processo, que é vedada pelo parágrafo $2^{\circ}$, inciso III do artigo 28-A, nos cinco anos seguintes à celebração de qualquer um deles).

Em contrapartida, se o investigado não cumprir com as condições estabelecidas no acordo o Ministério Público comunicará o fato ao juízo competente e oferecerá denúncia, nos termos do parágrafo 10 do mesmo artigo, além de utilizar-se do não cumprimento do acordo para fundamentar a recusa a um eventual pedido de suspensão condicional do processo, conforme disposto no parágrafo 11.

Ressalta-se ainda que, de acordo com o previsto no parágrafo 9ํำ do artigo 28-A, a vítima será sempre comunicada dos atos, tanto no tocante à celebração do acordo quanto no eventual descumprimento dele.

Após análise das questões pertinentes à homologação ou não do acordo pelo Poder Judiciário, a seguir as interpretações conferidas pelos Tribunais de Justiça.

\subsection{0 acordo de não persecução penal nos tribunais}

Em se tratando de instituto novo no ordenamento jurídico, não é incomum que surjam inúmeras dúvidas quanto a sua aplicabilidade e, sobretudo, quanto às lacunas deixadas pela lei, não sendo esta específica em algumas peculiares definições.

Destarte, evidencia-se com a realização da presente pesquisa que há divergência de entendimentos na aplicação do acordo de não persecução penal entre diversos tribunais do Brasil. Destaque para 
dúvidas quanto ao acordo ser aplicável somente antes do recebimento da denúncia ou se é possível o seu oferecimento em processos em andamento quando da entrada em vigor da lei, inclusive já em fase recursal.

Para demonstrar a divergência jurisprudencial nos tribunais, colaciona-se a seguinte ementa julgada em 24 de setembro de 2020 pela quarta câmara criminal do Tribunal de Justiça do Rio Grande do Sul, em que se sustentou a aplicabilidade do acordo de não persecução penal em processos em curso, desde que o processo não tenha transitado em julgado:

EMENTA: HABEAS CORPUS. ART. 15, DA LEI № 10.826/2006. ACORDO DE NÃO PERSECUÇÃO PENAL. ART. 28-A DO CPP. DENÚNCIA RECEBIDA. NORMA PROCESSUAL HÍBRIDA. RETROATIVIDADE. DENÚNCIA RECEBIDA. PROCESSO SEM SENTENÇA. POSSIBILIDADE. LIMINAR CONCEDIDA E TORNADA DEFINITIVA. 1. Paciente denunciado pelo crime de disparo de arma de fogo que teve negada a oferta de acordo de não persecução penal pelo Ministério Público porque já recebida a denúncia. 2. Tratando-se de norma processual híbrida, introduzida no ordenamento jurídico pela Lei no 13.964 19, admissível a retroatividade nos processos em andamento, desde que ainda não prolatada sentença penal condenatória, por interpretação analógica ao entendimento do STF quanto ao instituto da suspensão condicional do processo. 3. Liminar parcialmente concedida e tornada definitiva para, ultrapassado o óbice temporal da oferta do ANPP, remeter os autos ao Ministério Público para análise dos demais requisitos do acordo e pertinência da oferta. ORDEM PARCIALMENTE CONCEDIDA, POR MAIORIA(Habeas Corpus Criminal № 70084451046, Quarta Câmara Criminal, Tribunal de Justiça do RS, Relator: Julio Cesar Finger. Julgado em 24/09/2020, publicado em 12/11/2020, grifo nosso).

Salienta-se que distante menos de um mês (dia 19 de outubro de 2020) foi julgado pela sétima câmara criminal do mesmo tribunal um caso análogo em que a decisão foi contrária àquela proferida pela quarta câmara criminal. Agora, posicionando-se no sentido de que o momento para a aplicação do acordo de não persecução penal é anterior ao recebimento da denúncia:

EMENTA: HABEAS CORPUS. CRIMES DE TRÂNSITO. APLICAÇÃO DO ART. 28-A DO CÓDIGO DE PROCESSO PENAL. IRRETROATIVIDADE DA LEI 13.964/2019. AUSÊNCIA DE CONSTRANGIMENTO ILEGAL NA DECISÃO QUE INDEFERIU O PEDIDO DEFENSIVO DE APLICAÇÃO DO INSTITUTO DO ACORDO DE NÃO PERSECUÇÃO PENAL. DENÚNCIA RECEBIDA ANTERIORMENTE À ENTRADA EM VIGOR DA REFERIDA LEI. PRECEDENTES DO STJ. Tendo sido a denúncia recebida anteriormente à vigência da Lei no 13.964/2019, não há falar em aplicação do artigo 28-A do Código de Processo Penal, que prevê que o acordo de não persecução penal será efetivado, com a observância dos requisitos objetivos e subjetivos, se não for o caso de arquivamento, pressupondo, assim, que o momento para a sua aplicação é anterior ao recebimento da denúncia. Precedentes do Superior Tribunal de Justiça. HABEAS CORPUS DENEGADO (Habeas Corpus Criminal № 70084537208, Sétima Câmara Criminal, Tribunal de Justiça do RS, Relator: José Conrado Kurtz de Souza. Julgado em 19/10/2020, publicado em 21/10/2020, grifo nosso).

Frisa-se que ambas as ementas jurisprudenciais supratranscritas foram proferidas pelo mesmo tribunal (apesar de Câmaras Criminais diversas - 4aa e 7aㅡ) em Sede de Habeas Corpus, cuja autoridade coatora é a mesma - o Juiz de Direito da 1 ${ }^{\underline{a}}$ Vara Criminal da Comarca de Erechim. Desse modo, percebese que pelo fato do tribunal divergir em seu posicionamento, os pacientes que pleitearam o mesmo direito, na mesma comarca, foram atendidos de forma diversa pelo Poder Judiciário.

Recente entendimento da oitava câmara criminal do Tribunal de Justiça do Rio Grande do Sul foi no sentido de ser inaplicável o acordo de não persecução penal se já recebida a denúncia:

EMENTA: EMBARGOS DE DECLARAÇÃO. CRIMES CONTRA O PATRIMÔNIO. FURTO DE ENERGIA ELÉTRICA QUALIFICADO PELO ROMPIMENTO DE OBSTÁCULO. PLEITO DE REMESSA DOS AUTOS À ORIGEM PARA QUE SEJA OFERECIDO AO EMBARGANTE O ACORDO DE NÃO PERSECUÇÃO PENAL, NOS TERMOS DO ARTIGO 28-A DO CPP, INCLUÍDO PELA LEI № 13.964/2019. REJEIÇÃO. A Lei nº 13.964/2019, alinhando-se ao que já constava da Resolução no 181/2017 do CNMP, incorporou ao ordenamento jurídico pátrio o denominado acordo de não persecução penal, agora previsto no artigo 28-A do CPP. Trata-se de negócio jurídico pré-processual, inexistindo direito público subjetivo do réu à sua celebração, porquanto poder-dever do Ministério 
Público, a quem cabe analisar, com exclusividade, seu cabimento, sempre de forma fundamentada. Por outro lado, mesmo que não se ignore o conteúdo híbrido do novo dispositivo, que pode resultar, caso cumpridas as condições do acordo, na extinção da punibilidade do investigado, a aplicação retroativa do artigo 28-A do CPP somente tem cabimento em relação aos processos em que ainda não recebida a denúncia.Assim o enunciado no 20, produzido pelo GNCCRIM e aprovado pelo CNPG, ao interpretar o novo dispositivo, entendendo que cabe acordo de não persecução penal para fatos ocorridos antes da vigência da Lei no $13.964 / 2019$, desde que não recebida a denúncia, bem como recente jurisprudência do e. STJ. Portanto, não há falar, aqui, na suspensão do feito e remessa dos autos à origem para que seja oportunizada ao embargante a celebração de acordo de não persecução penal. AMBIGUIDADE, OBSCURIDADE, CONTRADIÇÃO OU OMISSÃO. INEXISTÊNCIA. Não houve omissão, ambiguidade, obscuridade ou contradição no acórdão, que enfrentou a condenação do embargante, de forma clara, inclusive no tocante às teses defensivas relacionadas à ausência de laudos periciais, excludente de ilicitude do estado de necessidade e causa de diminuição do $\$ 2^{o}$ do artigo 24 do CP, furto privilegiado e qualificadora do rompimento de obstáculo, com o final desprovimento do apelo. PREQUESTIONAMENTO DE DISPOSITIVOS CONSTITUCIONAIS E INFRACONSTITUCIONAIS. Os embargos declaratórios, ainda que com fins de prequestionamento, devem atender ao disposto do artigo 619 do CPP. Se presente decisão fundamentada que dirime a lide, com base em posição sedimentada da Câmara competente para apreciar a matéria, não há exigência de debater artigos suscitados pelas partes, até mesmo por não obstar a interposição de recurso especial ou extraordinário. EMBARGOS DE DECLARAÇÃO DESACOLHIDOS (Embargos de Declaração Criminal № 70084547702, Oitava Câmara Criminal, Tribunal de Justiça do RS, Relator: Isabel de Borba Lucas. Julgado em 28/10/2020, grifo nosso).

Além das divergências já apontadas na jurisdição estadual, analisar-se-á o posicionamento do Tribunal Regional Federal da $4^{\underline{a}}$ Região, competente para julgar os crimes de jurisdição federal.

Neste tribunal, encontrou-se um julgamento realizado em 16 de outubro de 2020, em que a sétima turma, utilizando-se de precedente da quarta turma deste tribunal, decidiu pela aplicação do acordo de não persecução penal aos processos que já estavam em curso. Isto é, processos em que a denúncia já havia sido recebida, inclusive em grau de recurso:

EMENTA: PROCESSUAL PENAL. EMBARGOS DE DECLARAÇÃO. ART. 619 DO CPP. INEXISTÊNCIA DE OMISSÃO, AMBIGUIDADE, OBSCURIDADE OU CONTRADIÇÃO. REDISCUSSÃO. ACORDO DE NÃO PERSECUÇÃO PENAL APÓS O RECEBIMENTO DA DENÚNCIA. ART. 28-A DO CPP. POSSIBILIDADE. REQUISITOS OBJETIVOS. NÃO ATENDIMENTO. 1. Os embargos declaratórios não são o meio próprio para que se obtenha o rejulgamento da causa ou para se adaptar a decisão ao entendimento do embargante, tampouco para que se acolham pretensões que refletem mero inconformismo. 2. Na hipótese vertente, ao contrário das razões recursais, verifica-se que o Colegiado enfrentou detalhadamente a questão objeto dos declaratórios. 3. No ponto, o que se constata é inconformismo dos embargantes com a análise promovida, importando em rediscussão vedada nesta via. 4. Conforme entendimento firmado pela 4⿳a Seção deste Tribunal, é possível aplicação de acordo de não persecução penal (art. 28-A, CPP) aos processos com denúncia já recebida na data da vigência da Lei n.o 13.964/2019, inclusive para aqueles em grau de recurso (EINF n.o 5001103-25.2017.404.7109/RS). 5. No caso em tela, não se viabiliza o acordo de não persecução penal uma vez que da inicial deflui pena mínima superior a quatro anos, consideradas as causas de diminuição e de aumento (TRF4, ACR no 5006074-86.2017.4.04.7001, Sétima Turma, Relatora Salise Monteiro Sanchotene. Juntado aos autos em 16/10/2020, publicado em 16/10/2020, grifo nosso).

No caso em apreciação, o acordo de não persecução penal deixou de ser aplicável dada a pena mínima extrapolar a quantidade permitida para a celebração; entretanto, garantiu-se, através de precedente, a possibilidade de sua celebração mesmo no curso do processo. A mesma turma, recentemente, julgou de modo diverso quanto à interpretação do acordo:

EMENTA: PENAL. ART. 334 DO CÓDIGO PENAL. DESCAMINHO. ACORDO DE NÃO PERSECUÇÃO PENAL. IMPOSSIBILIDADE. PRINCÍPIO DA INSIGNIFICÂNCIA. HABITUALIDADE DELITIVA. MATERIALIDADE, AUTORIA E DOLO COMPROVADOS. INEXIGIBILIDADE DE CONDUTA DIVERSA. NÃO RECONHECIMENTO. CONDENAÇÃO MANTIDA. DOSIMETRIA DA PENA. PENA RESTRITIVA DE DIREITO. PRESTAÇÃO DE SERVIÇOS À COMUNIDADE. 1. É o recebimento da denúncia o marco que o legislador decidiu que fosse 
considerado para a incidência da nova regra que dispõe sobre o acordo de não persecução penal. 2. Comprovada a contumácia na prática delitiva, tem-se caracterizada a reprovabilidade da conduta de modo a afastar a aplicação do princípio da insignificância, ainda que o montante de tributos iludidos seja inferior a R $\$ 20.000,00$ (vinte mil reais). 3. Trata-se do crime de descaminho, ou seja, a conduta de importar ou exportar mercadoria valendo-se de fraude para evitar o pagamento de direito ou imposto devido pela entrada ou saída de mercadoria não proibida. 4. Nos crimes de descaminho, a materialidade e a autoria são comprovadas, em regra, com os documentos elaborados e lavrados pela autoridade fiscal competente e responsável pela diligência por ocasião da apreensão das mercadorias. 5. O dolo trata-se de elemento subjetivo estruturado de modo genérico no tipo penal em questão, motivo pelo qual se deve aferi-lo pela prática consciente e deliberada da conduta descrita no preceito primário da norma penal imputada ao réu. 6. A mera insuficiência de recursos não caracteriza o estado de necessidade ou a situação de inexigibilidade de conduta diversa. 7. Presente prova da materialidade, da autoria e do dolo no agir, bem como inexistentes causas excludentes da culpabilidade ou da ilicitude, impõe-se manter a condenação. 8. A prestação de serviço à comunidade ou entidades públicas é considerada como a que melhor cumpre a finalidade de reeducação e ressocialização do agente, nos moldes da Súmula no 132 (ACR no 5002963-70.2017.4.04.7106, Sétima Turma, TRF4, Relatora Salise Monteiro Sanchotene. Juntado aos autos em 28/10/2020, publicado em 28/10/2020, grifo nosso).

Após a análise de divergências regionalizadas, tanto no Tribunal de Justiça do Rio Grande do Sul quanto no Tribunal Regional Federal da Quarta Região, percebeu-se a influência dessas decisões proferidas pelo Superior Tribunal de Justiça, apesar de suas turmas também divergirem sobre o novo instituto de justiça penal consensual. Nessa seara, colacionam-se duas jurisprudências nas quais se verifica a dissonância de entendimentos.

A quinta turma do Superior Tribunal de Justiça decidiu não ser aplicável o acordo de não persecução penal quando já recebida a denúncia:

PROCESSO PENAL. EMBARGOS DE DECLARAÇÃO NO AGRAVO REGIMENTAL NO AGRAVO REGIMENTAL NO AGRAVO EM RECURSO ESPECIAL. TRÁFICO DE DROGAS. APLICAÇÃO DO ART. 28-A DO CPP. IMPOSSIBILIDADE. PECULIARIDADE DO CASO. RECONHECIMENTO DA CAUSA DE DIMINUIÇÃO EM SEDE DE RECURSO ESPECIAL. EMBARGOS DE DECLARAÇÃO REJEITADOS. 1. Segundo o $\$ 1^{\circ}$ do art. 28-A do Código de Processo Penal, para aferição da pena mínima cominada ao delito a que se refere o caput deste artigo, serão consideradas as causas de aumento e diminuição aplicáveis ao caso concreto. 2. Para serem consideradas as causas de aumento e diminuição, para aplicação do Acordo de Não Persecução Penal (ANPP), essas devem estar descritas na denúncia, que, no presente caso, inocorreu, não sendo possível considerar, no cálculo da pena mínima cominada ao crime imputado ao acusado, a causa de diminuição reconhecida apenas quando do julgamento do recurso especial. No caso do delito de tráfico, far-se-á necessário o curso da ação penal, em regra, para aferir os requisitos previstos no art. $33, \S 4^{\circ}$, da Lei $n^{\circ}$ 11.343/06, o que obsta a aplicação do benefício, que decorre, inclusive do tratamento constitucional e da lei que são rigorosos na repressão contra o tráfico de drogas, crime grave, que assola o país, merecendo um maior rigor estatal. 3. Mostra-se incompatível com o propósito do instituto do Acordo de Não Persecução Penal (ANPP) quando já recebida a denúncia e já encerrada a prestação jurisdicional na instância ordinária, com a condenação do acusado, cuja causa de diminuição do art. 33, §4º da Lei de drogas fora reconhecida somente neste STJ, com a manutenção da condenação. 4. Embargos de declaração rejeitados (EDcl no AgRg no AgRg no AREspno 1635787/SP, Quinta Turma, Rel.Ministro Reynaldo Soares da Fonseca.Julgado em 04/08/2020, publicado em 13/08/2020, grifo nosso).

Em que pese o entendimento da quinta turma ser no intuito de não cabimento do acordo de não persecução penal, a sexta turma do mesmo tribunal proferiu decisão de que o novo instituto deve ser aplicado a processos já em andamento, desde que não transitados em julgado:

AGRAVO REGIMENTAL NO HABEAS CORPUS. FRAUDE À LICITAÇÃO. FALSIDADE IDEOLÓGICA. ACORDO DE NÃO PERSECUÇÃO PENAL. PACOTE ANTICRIME. ART. 28-A DO CÓDIGO DE PROCESSO PENAL. NORMA PENAL DE NATURA MISTA. RETROATIVIDADE A FAVOR DO RÉU. NECESSIDADE DE INTIMAÇÃO DO MINISTÉRIO PÚBLICO. DECISÃO RECONSIDERADA. AGRAVO REGIMENTAL PROVIDO. 1. É reconsiderada a decisão inicial porque o cumprimento integral do acordo de não persecução penal gera a extinção da punibilidade (art. 28-A, § 13, do CPP), de modo que como norma de natureza jurídica mista e mais 
benéfica ao réu, deve retroagir em seu benefício em processos não transitados em julgado (art. 5ํㅜ, XL, da CF). 2. Agravo regimental provido, determinando a baixa dos autos ao juízo de origem para que suspenda a ação penal e intime o Ministério Público acerca de eventual interesse na propositura de acordo de não persecução penal, nos termos do art. 28-A do CPP (introduzido pelo Pacote Anticrime - Lei n. 13.964/2019) (AgRg no HC nº 575.395/ RN, Sexta Turma, Rel. Ministro Nefi Cordeiro. Julgado em 08/09/2020, publicado em 14/09/2020, grifo nosso).

Dadas as divergências vislumbradas em tribunais do Brasil, o Ministro do Supremo Tribunal Federal, Gilmar Mendes, utilizou-se da decisão supra para deliberar e decidir em Plenário da Corte o processo em que o paciente requereu o benefício do acordo - e aproveitou o momento para fixar entendimento no tocante à temporalidade de sua aplicação:

Constato que a possibilidade de aplicação do art. 28-A do CPP (inserido pela Lei 13.964/19) - que previu o denominado acordo de não persecução penal - a processos em curso tem sido objeto de intenso debate doutrinário e jurisprudencial no que diz respeito à sua natureza e consequente retroatividade mais benéfica (BRASIL, Supremo Tribunal Federal, Habeas Corpus no 185.913 , 2020, texto digital).

Como visto, o Ministro sustentou ser imprescindível levar à corte a demanda para resguardar a segurança jurídica e a previsibilidade das situações processuais. Diante disso, remeteu para deliberação no plenário, delimitando o tema aos seguintes questionamentos:

a) o acordo de não persecução penal pode ser oferecido em processos já em curso quando do surgimento da Lei 13.964/19? Qual é a natureza da norma inserida no art. 28-A do CPP? É possível a sua aplicação retroativa em benefício do imputado?

b) é potencialmente cabível o oferecimento do acordo de não persecução penal mesmo em casos nos quais o imputado não tenha confessado anteriormente, durante a investigação ou o processo? (BRASIL, Supremo Tribunal Federal, Habeas Corpus no185.913, 2020).

Por fim, defendeu que a questão é de interesse jurídico e social, assim como de interpretação constitucional e que gera divergência entre julgados, devendo o Supremo Tribunal Federal assentar precedente com eventual tese para utilização em todos os tribunais brasileiros, criando-se precedente jurisprudencial acerca do tema, possibilitando julgamentos uniformes no âmbito do Poder Judiciário (BRASIL, Supremo Tribunal Federal, Habeas Corpus n⿳o 185.913, 2020).

\section{Considerações Finais}

O acordo de não persecução é um instituto de justiça penal consensual, e que a sua criação certamente foi inspirada nos demais modelos consensuais já existentes no ordenamento jurídico, visto que estão guarnecidos de legalidade e subsidiam a implementação de mais outros modelos de resolução consensual.

O modelo consensual de resolução de crimes possibilita benefícios ao próprio investigado (desde que colabore com a investigação), uma vez que possibilita livrar-se de forma menos morosa do processo ao cumprir com as condições ajustadas. Situação que não é possível quando da persecução penal, onde o autor pode acabar sofrendo imputações severas, além de eventual desgaste físico e psicológico.

Através de pesquisa jurisprudencial no Tribunal de Justiça do Estado do Rio Grande do Sul, no Tribunal Regional Federal da $4^{\underline{a}}$ Região e no Superior Tribunal de Justiça, restou demonstrados posicionamentos diversos referentes à aplicação do acordo de não persecução penal no tempo. Tanto que o Ministro Gilmar Mendes, do Supremo Tribunal Federal, remeteu a discussão ao plenário da Corte, por ser indispensável firmar entendimento quanto ao momento certo para se celebrar o acordo - antes do recebimento da denúncia ou também após.

Por derradeiro, importante firmar precedentes relativos ao tema, para que não ocorra a injustiça aos autores dos fatos que pleiteiam direitos iguais, mas obtêm decisões divergentes - como demonstrado no decorrer da pesquisa (quando em processos advindos da mesma comarca resultaram decisões diversas proferidas pelo mesmo tribunal). 


\section{Referências}

ALVES. Jamil Chaim. Justiça Consensual e PleaBargaining. In: CUNHA, Rogério Sanches et al. Acordo de não persecução penal. Salvador: Editora JusPodivm, 2020. p. 235-256.

ARAS. Vladimir. Acordos penais no Brasil: uma análise à luz do direito comparado. In:CUNHA, Rogério Sanches et al. Acordo de não persecução penal. Salvador: Editora JusPodivm, 2020. p. 291-347

ARAÚJO, Fábio Roque; COSTA, Klaus Negri. Processo Penal Didático. 3. ed. Salvador: JusPodivm, 2020.

AVENA, Norberto. Processo Penal. 11. ed. Forense: São Paulo: Método, 2019. E-book. Disponível em: www.univates.br/biblioteca. Acesso em: 10 out. 2020.

BARROS, Francisco Dirceu; ROMANIUC, Jefson. Acordo de não persecução penal: teoria e prática. 3 ed. São Paulo: JH Mizuno, 2019.

BARROS, Francisco Dirceu; ROMANIUC, Jefson.Constitucionalidade do acordo de não-persecução penal. In: CUNHA, Rogério Sanches et al. Acordo de não persecução penal. Salvador: Editora JusPodivm, 2020. p. 59-110.

BATTINI, Lucas Andrey; BORRIS, Luiz Antonio; SOARES, Rafael Junior. Breves considerações do instituto do acordo de não persecução penal. Revista do Instituto de Ciências Penais, Belo Horizonte, v. 5, p. 213-232, maio 2020. Disponível em: http://icp.org.br/DocRicp/Volume\%205. pdf. Acesso em: 25 out. 2020.

BRASIL. [Constituição (1988)]. Constituição da República Federativa do Brasil. Brasília, DF: Presidência da República, [2020]. Disponível em: http://www.planalto.gov.br/ccivil 03/ constituicao/constituicaocompilado.htm. Acesso em: 10 out 2020.

BRASIL. Decreto-Lei n ${ }^{\circ}$ 2.848, de 07 de dezembro de 1940. Código Penal. Disponível em: http: // www.planalto.gov.br/ccivil 03/decreto-lei/del2848compilado.htm. Acesso em: 31 out. 2020.

BRASIL. Decreto-Lei n 3.689, de 03 de outubro de 1941.Código de Processo Penal. Disponível em: http://www.planalto.gov.br/ccivil 03/decreto-lei/del3689.htm. Acesso em: 31 out. 2020.

BRASIL. Lei no 8.072, de 25 de julho de 1990. Dispõe sobre os crimes hediondos, nos termos do art. $5^{\mathrm{o}}$, inciso XLIII, da Constituição Federal, e determina outras providências. Disponível em: http://www.planalto.gov.br/ccivil_03/leis/18072.htm. Acesso em: 10 out. 2020.

BRASIL. Lei no 9.099, de 26 de setembro de 1995.Dispõe sobre os Juizados Especiais Cíveis e Criminais e dá outras providências. Disponível em: http://www.planalto.gov.br/ccivil_03/leis/ 19099.htm. Acesso em: 10 out. 2020.

BRASIL. Lei n⿳o 10.826, de 22 de dezembro de 2003. Dispõe sobre registro, posse e comercialização de armas de fogo e munição, sobre o Sistema Nacional de Armas - Sinarm, define crimes e dá outras providências. Disponível em: http://www.planalto.gov.br/ccivil 03/leis/2003/110.826. htm. Acesso em: 24 out. 2020.

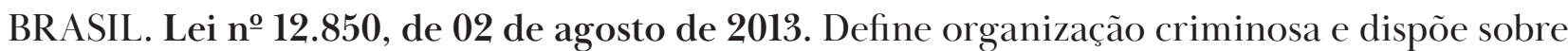
a investigação criminal, os meios de obtenção da prova, infrações penais correlatas e o procedimento criminal; altera o Decreto-Lei no 2.848, de 7 de dezembro de 1940 (Código Penal); revoga a Lei no 9.034, de 3 de maio de 1995; e dá outras providências. Disponível em: http://www.planalto.gov.br/ccivil_03/_ato2011-2014/2013/lei/112850.htm. Acesso em: 10 out. 2020.

BRASIL. Supremo Tribunal Federal. Ação Direta de Inconstitucionalidade (Med Liminar) - $\mathbf{n}^{\mathbf{0}}$ 6299. Brasília. 22 jan. 2020. Disponível em: http://portal.stf.jus.br/processos/downloadPeca. asp?id=15342203609\&ext=.pdf. Acesso em: 25 out. 2020. 
BRASIL. Superior Tribunal de Justiça. Embargos de Declaração no Agravo Regimental no Agravo Regimental no Agravo em Recurso Especial no 1.635.787 / SP (2019/03757230). Ministro Relator: Reynaldo Soares da Fonseca. Brasília, 13 ago. 2020. Disponível em: https://scon.stj.jus.br/SCON/GetInteiroTeorDoAcordao?num registro $=201903757230 \& d t$ publicacao $=13 / 08 / 2020$. Acesso em: 11 nov. 2020.

BRASIL. Superior Tribunal de Justiça. Agravo Regimental no Habeas Corpus no 575.395 / RN (2020/0093131-0). Ministro Relator: Nefi Cordeiro. Brasília, 14 set. 2020. Disponível em https://scon.stj.jus.br/SCON/GetInteiroTeorDoAcordao? num registro $=202000931310 \& d t$ publicacao $=14 / 09 / 2020$. Acesso em: 11 nov. 2020.

BRASIL. Supremo Tribunal Federal. Habeas Corpus no 185.913. Ministro Relator: Gilmar Mendes. Brasília, 22 set. 2020. Disponível em: http://portal.stf.jus.br/processos/downloadPeca. asp?id=15344488197\&ext=.pdf. Acesso em: 03 nov. 2020.

BRASIL. Tribunal Regional Federal (4. Região). Apelação Criminal no 500607486.2017.4.04.7001. Relatora: Salise Monteiro Sanchotene. Porto Alegre, 16 out. 2020. Disponível em: https://jurisprudencia.trf4.jus.br/pesquisa/inteiro teor.php?orgao $=1 \&$ numero gproc $=40002032222 \& v e r s a 0$ gproc $=10 \& c r c$ gproc $=4267 \mathrm{de} 01 \&$ termosPesquisados $=\mathrm{bGVpIDEzOTY0IGFjb3JkbyA=.} \mathrm{Acesso} \mathrm{em:} 31$ out. 2020 .

BRASIL. Tribunal Regional Federal (4. Região). Apelação Criminal no 5002963-

70.2017.4.04.7106. Relatora: Salise Monteiro Sanchotene. Porto Alegre, 28 out. 2020. Disponível em: https://jurisprudencia.trf4.jus.br/pesquisa/ inteiro teor.php?orgao $=1 \&$ numero gproc $=40002103482 \&$ versao gproc $=3 \& \mathrm{crc}$ gproc=81e2354c\&termosPesquisados=bGVpIDEzOTY0IGFjb3JkbyA=. Acesso em: 03 nov. 2020 .

CABRAL, Rodrigo Leite Ferreira. Um panorama sobre o acordo de não persecução penal (art. 18 da resolução n. 181/17-cnmp, com as alterações da resolução n. 183/18-cnmp - versão ampliada e revisada. In: CUNHA, Rogério Sanches et al. Acordo de não persecução penal. Salvador: Editora JusPodivm, 2020. p. 21-57.

CONSELHO NACIONAL DO MINISTÉRIO PÚBLICO. Resolução no 181, de 7 de agosto de 2017. Disponível em: https://www.cnmp.mp.br/portal/images/Resolucoes/Resoluo-181-1.pdf. Acesso em: 25 set. 2020.

CONSELHO NACIONAL DO MINISTÉRIO PÚBLICO. Resolução no 183, de 24 de janeiro de 2018. Disponível em: https://www.cnmp.mp.br/portal/images/Resolucoes/Resoluo-183.pdf. Acesso em: 25 set. 2020.

COSTA, Antonio Martins et al. Acordo de não persecução penal. Revista da Defensoria Publicado Estado do Rio Grande do Sul, Porto Alegre, ano 11, n. 26, p. 42-64, 2020.

CUNHA, Vítor Souza. Acordos de Admissão de Culpa no Processo Penal. Salvador: Editora JusPodivm, 2019.

CUNHA, Vítor Souza.Rogério Sanches. Pacote Anticrime - Lei 13.964/2019: comentários às alterações no CP, CPP e LEP.Salvador: Editora Juspodivm, 2020.

DOWER, Patrícia Eleutério Campos; SOUZA, Renee do Ó. Algumas respostas sobre o acordo de não persecução penal. In: CUNHA, Rogério Sanches et al. Acordo de não persecução penal. Salvador: JusPodivm, 2020. p. 143-189.

FERREIRA, Lucas César Costa. A nova disciplina do acordo de não persecução penal: implicações práticas para o ministério público. In: BRASIL. Ministério Público Federal. 2ª Câmara de Coordenação e Revisão. Inovações da Lei no 13.964, de 24 de dezembro de 2019.Walmsley, Andréa; CIRENO, Lígia; BARBOZA, Márcia Noll (Orgs). Brasília: MPF, 2020. 444 p. (Coletânea de artigos; v. 7). p. 314-328. Disponível em: http://www.mpf.mp.br/atuacao-tematica/ccr2/ publicacoes. Acesso em: 28 out. 2020. 
GRUPO NACIONAL DE COORDENADORES DE CENTRO DE APOIO CRIMINAL - GNCCRIM. Enunciados interpretativos da Lei no 13.964/2019 - Lei Anticrime. 2019. Disponível em: https://www.cnpg.org.br/images/arquivos/gndh/documentos/enunciados/GNCCRIM_ Enunciados.pdf. Acesso em: 31 out. 2020.

LOPES JUNIOR, Aury. Direito Processual Penal. 17. ed. São Paulo: Saraiva Educação, 2020.

MASI, Carlo Velho. Acordo de não persecução penal como ferramenta de político-criminal de despenalização dos crimes de médio potencial ofensivo. Revista da Defensoria Publicado Estado do Rio Grande do Sul, Porto Alegre, ano 11, n. 26, p. 264-293, 2020.

MENDONÇA, Ana Cristina. A defesa técnica e o acordo de não persecução penal. In: CUNHA, Rogério Sanches et al. Acordo de não persecução penal. Salvador: Editora JusPodivm, 2020. p. 363-376.

MESSIAS, Mauro. Acordo de não persecução penal: teoria e prática. Rio de Janeiro: Lumen Juris, 2019.

MOSSIN, Heráclito Antônio; MOSSIN Júlio César O. G. Doutrina e Prática Processo Penal. 3 ed. São Paulo: JH Mizuno, 2020.

RIO GRANDE DO SUL. Tribunal de Justiça. Habeas Corpus no 70084537208, 7ª Câmara Criminal. Relator: José Conrado Kurtz de Souza. Porto Alegre, 21 out. 2020. Disponível em: https://www. tjrs.jus.br/novo/buscas-solr/?aba=jurisprudencia\&q $=70084537208 \&$ conteudo busca $=$ ementa completa. Acesso em: 30 out. 2020.

RIO GRANDE DO SUL. Tribunal de Justiça. Embargos de Declaração no 70084547702 , da $8^{\text {a }}$ Câmara Criminal. Relatora: Isabel de Borba Lucas. Porto Alegre, 28 out. 2020. Disponível em: https://www.tjrs.jus.br/novo/buscas-solr/?aba=jurisprudencia\&q=70084547702\&conteu do_busca=ementa_completa. Acesso em: 03 nov. 2020.

RIO GRANDE DO SUL. Tribunal de Justiça. Habeas Corpus no 70084451046 , da $4^{\text {a }}$ Câmara Criminal. Relator: Julio Cesar Finger. Porto Alegre, 12nov. 2020. Disponível em: https://www. tjrs.jus.br/novo/buscas-solr/?aba=jurisprudencia\&q $=70084451046 \&$ conteudo busca $=$ ementa completa. Acesso em: 15nov. 2020.

SILVA, Franklyn Roger Alves. Acordo de não persecução penal. Revista da Defensoria Publicado Estado do Rio Grande do Sul, Porto Alegre, ano 11, n. 26, p. 367-422, 2020.

VASCONCELLOS, Vinicius Gomes de. Colaboração premiada no processo penal. São Paulo: Revista dos Tribunais, 2017. 